\title{
Gamma Irradiator Facilities for Processing Plant Industries Products
}

\author{
Ari Satmoko ${ }^{1 *}$ Tanti Ardiyati ${ }^{1}$, and Hyundianto Arif Gunawan ${ }^{1}$ \\ ${ }^{1}$ Center for Nuclear Facilities Engineering - BATAN, Kawasan Puspiptek Gedung 71, Tangerang Selatan, 15310, Indonesia
}

\begin{abstract}
Indonesia is rich in diversity of agroindustrial products. Yet the tropical climate causes agroindustrial products being easily damaged. Techniques for food preservation have been widely known such as drying, cooling or freezing, canning, chemical use and others. To complement these techniques, a promising unconservative technique using ionizing radiation can be safely used to preserve food, without leaving residual radiation or hazardous chemical residues. Unfortunately in Indonesia, the irradiation technique was still not common since few industries have used this technique. Compared to the neighbouring countries, only Indonesia as a big country had no interest in developing irradiator technology. To introduce this technique to the public, especially investors, BATAN in 2017 built a pilot project named as Iradiator Gamma Merah Putih (IGMP). It was designed with maximum activity up to $2 \mathrm{MCi}$ using Cobalt-60 as radioactive sources and can serve from low to high dose. By the time, the number of agroindustrial customers, as well as their quantity to be processed, are increasing. The irradiation technique becomes an appropriate technology for Indonesian agroindustries. It is then necessary to build gamma irradiation facilities in areas that have large agricultural yields. This way can minimalize crop losses and increase the quality of the agricultural products.
\end{abstract}

\section{INTRODUCTION}

As a tropical country, Indonesia is rich in diversity of agroindustrial products. Yet, the tropical climate causes agro-industrial and processed products being easily damaged. Techniques for food preservation have been widely known such as drying, cooling or freezing, canning, chemical use and others.

An unconservative technique using ionizing irradiation can be safely used to preserve food, without leaving residual radiation or hazardous chemical residues. Ionizing rays will result in killing microorganisms but do not damage the food itself. The clearing of preservative food using irradiation technique has been given because it meets three requirements aspects in nutrition, microbiology and toxicology. The irradiation technique becomes an appropriate technology for Indonesia. Unfortunately, in Indonesia the irradiation technique was still not common, since few agroindustries have used this technique.

To disseminate this technique to the public, especially investors, BATAN built a pilot project of the gamma irradiator facility [1]. After inaugurated as Iradiator Gamma Merah Putih (IGMP) at the end of 2017, the irradiator after then began in operation. Currently, IGMP obtains customers from various private companies in which among them are a new customer in irradiation application. By the time, the number of customers, as well as its quantity to be processed, is increasing.
However, the usage of a gamma irradiator facility has still not been significant until today, thus socialization to the public is needed. To date in Indonesia, there are several irradiation facilities owned by government and private sector. Government or BATAN has few irradiation facilities used for research purposes for small product capacity. Irradiation facility owned by private sector is belong to PT. Rel Ion and was commercially used since 1991. Nowadays, the queue for the irradiation services in PT. Rel Ion is quite long, so that the customers have to wait for long period of time. Looking into this phenomenon, the investors is still not interested to build another commercial irradiation facility. Since the analysis study of the needs of gamma irradiator in Indonesia are considerably, BATAN built IGMP as pilot project prototype. The aims of this project are to show that IGMP is commercially viable and then many investors are interested in building this facility.

This paper will discuss about irradiated food, irradiator technology, characteristics of IGMP, also potential application of gamma irradiators for plant industries. This paper is expected would be an experience sharing from BATAN and basic knowledge to be applied nationwide. 


\section{Review on Irradiation Food Technology}

\subsection{Irradiated Food}

Food irradiation is the process of exposing food to ionizing radiation: gamma rays, $\mathrm{x}$-rays, or electron beams. Researches on irradiation food have been developed for a long time, and the application continues to increase worldwide. National and international regulations allow the use of irradiation technique for food. The World Health Organization (WHO) has also confirmed that irradiation is safe to be applied for food. Until today, the irradiation technique has been used for food products in more than 50 countries. The irradiation itself can serve many purposes, i.e:

- to eliminate harmful organisms, such as Salmonella and Escherichia coli;

- to destroy or inactivate organisms that cause spoilage and decomposition and to extend the shelf life of foods;

- to control and destroy insects in or on fresh fruits (phytosanitary);

- to increase longevity by delaying of sprouting (e.g., onions, potatoes) and of ripening (e.g., mangoes, bananas);

- to sterilize foods, especially for patients with severely impaired immune systems.

The treatments for the above purposes need a minimum to the maximum dose. The minimum dose is applied to ensure that the dose meets certain requirements such as killing insect eggs, larvae or other microorganisms. Meanwhile, the maximum dose is to avoid excessive dose which probably deteriorates or damage the nutrient.

In Indonesia, irradiation is recognized as a technology for preserving food, preventing food damage from pathogenic microorganism and growth of sprout by using radioactive substances or accelerator [2]. The commercialization of irradiated food has been approved by the regulation of the Minister of Health [3]. Various foodstuffs are allowed to be treated using irradiation, including agricultural products either with low or high doses options depending on the treatment purposes. Fresh fruit and vegetables, can undergo irradiation process with a maximum dose limit between 1.0 and 2.5 kGy. Meanwhile, to extend the shelf life of processed products of vegetables and fruits, a maximum dose of $7.0 \mathrm{kGy}$ is recommended. In general, irradiation of food ingredients with an average dose of up to $10 \mathrm{kGy}$ is considered safe for human consumption. Even for certain products, higher doses of irradiation, up to 50 or $65 \mathrm{kGy}$, are acceptable.

National Drug and Food Agency of Indonesia (BPOM) have also recognized food irradiation technology. Besides, BPOM published some documents regarding good irradiation process. According to BPOM [4], cereal seeds are generally contaminated by pest insects such as Coleoptera (beetles), Lepidoptera (moths) and Arachimida (mites). Their level of resistance against radiation is various. To guarantee lethality in 24 hours, it needs a dose of 3-5 kGy. Only $0.5 \mathrm{kGy}$ dose is sufficient to kill out insect. With this dose, the insects will be sterile and die within a few weeks after their eating ability decreases.

\subsection{Irradiator Technology}

Irradiator technology uses ionizing rays such as gamma rays, X-rays or electron beams. Gamma rays are produced by radioactive material such as Cobalt-60 or Cesium-137. Electron beams are produced by an electron beam machine using electricity power. Meanwhile, Xrays are produced by using the same machine in which electron beams collide with tantalum material.

Gamma rays, like X-rays, offer an advantage since its capability to penetrate materials up to $1 \mathrm{~m}$ of thickness. Since the activity of radioactive material decays over time, gamma irradiator facilities will then be economic if operated for 24 hours. On the other hand, the use of radioactive material is one of disadvantage point since it must be an object that must be secured in appropriate ways. Even when the activity is no longer economic, its waste is still being the object to be secured.

Electron beams machines need a shorter time to obtain the same dose as gamma irradiator, yet the machines are only capable to penetrate material in a few $\mathrm{cm}$. Due to this limitation, X-rays can be a solution. However, the conversion ratio from electron beams into $\mathrm{X}$-ray is still lower than $8 \%$ and economically debatable. The electron beam machines do not use radioactive material, yet it consumes electric power.

Both gamma irradiator and electron beam machine are used worldwide today and complement each other. For continuous products, the gamma irradiator is economic, while for high dose rate with thin packaging, the electron beam machine is a way more ideal.

A typical principle of gamma irradiator facility is shown in Figure 1 [5]. Its radioactive sources are stored in a pool filled with demineralized water when not in use. During the operation, the radioactive source is lifted up above the pool. The irradiation room called as bunker, is confined by concrete wall as shielding with thickness more than $1.8 \mathrm{~m}$. There are two access ways for going into the bunker: (1) access for goods to be irradiated and (2) access for restricted operator during maintenance activities. 


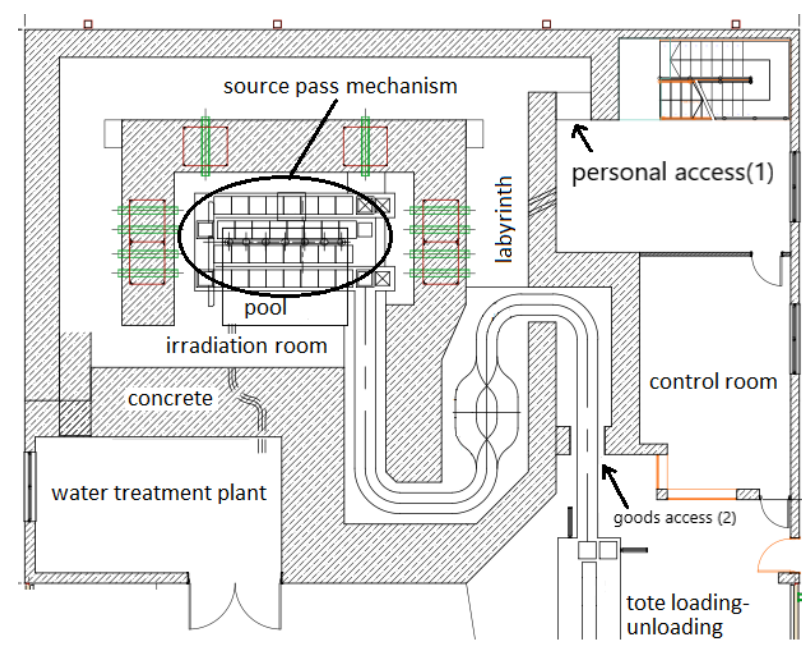

Fig. 1. Irradiation room of the IGMP

Products to be irradiated are usually packed into carton boxes. The carton boxes are then loaded into the tote boxes and transported one by one into the bunker using a couple of box cars drawn by a chain connected to an electric motor [5]. The adjacent box cars are transported out the tote box carrying the irradiated products. In the bunker, all tote boxes move through a track around the radioactive sources in order to receive uniform absorbed doses. The track has two levels and each level provides four lines. Axial movement in a lane, inter-lane transfer and level displacement with the help of an elevator are provided using a pneumatic mechanism.

\section{Characteristics of IGMP}

Started with the design in early 2015 , the construction of IGMP was finished and commissioned in the end of 2017. After obtaining the permission for operation from Bapeten as regulatory body, IGMP is now currently in operation.

\subsection{Radiation shielding design}

The IGMP facility is designed up to 2 MCi using Cobalt60 as radioactive sources. When not in operation mode, the sources are stored at the bottom of the pool which has dimension of $3.6 \times 2.8 \times 6.0 \mathrm{~m}^{3}$. The pool water serves as biological shielding. Under this condition, operators are safely and freely to perform maintenance activities. In operation mode, the sources are lifted above the pool. The irradiation room is surrounded by concrete wall with the thickness of $1.8 \mathrm{~m}$ which serves as biological shielding. The operators safely handle the facility via control room.

During the design phase, a special software was used to evaluate the potential of irradiation exposure. The pool water as shielding was analysed using MCNP software [6]. The pool with the dimension of $6.0 \mathrm{~m}$ in depth was modelled in layers as function of depth. The sources with total activity of $3 \mathrm{MCi}$ ( $150 \%$ of maximum design) were configured. From the MCNP results, combined with extrapolating method, it was found that at above pool surface, the irradiation rate was near zero. Concrete wall as shielding was also evaluated using MCNP software [7,8]. The configuration of the concrete wall (i.e. form and dimension) referred to the civil design. A $3 \mathrm{MCi}$ total activity of Cobalt-60 was modelled. The model showed that all areas outside the bunker were safe for the public. Aside from the computer modelling, the safety of IGMP also has been assured by the radiation exposures rate measurement. It was reported that the radiation exposures rate were below $0.2 \mu \mathrm{Sv} /$ hour inside and outside IGMP main building [9].

Beside against risk of potential radiation leak, the design also considered building integrity due to mechanical loads. They included dead load, live load and also external load (wind and earthquake) [10]. Analysis using computational code showed that the irradiator structure was safe against above mechanical loads.

\subsection{Mechanical aspect}

The main mechanical parts related to irradiation process are the source rack hoist mechanism and product transport system. The source rack hoist mechanism controls the source rack moving upward and downward. The movement is controlled by a pneumatic system. Its design is developed based on safety philosophy: in absence of neither mechanical nor electrical supplies, the source rack shall be moved downward to the bottom of the pool [11]. It is therefore safe for both product and operator. The source rack consists of three racks (Rack 1, Rack 2 and Rack 3) that can be independently controlled to move upward and downward [12].

The product transport system plays a role in bringing the products to get closer and farther away from radioactive sources (see Figure 2). The products to be irradiated is put into the tote box. When entering the bunker, a tote box is transported to the second storey using an ascending lift and moves through the track around the source racks. The tote box then goes down to the first storey using a descending lift and moves again through the track around the source racks. All the tote boxes movements are provided by pneumatic system which is designed such that all products in the tote box get a uniform irradiation absorbed dose. There are 84 tote box positions inside the bunker, but only 72 positions are in the irradiation positions. In the other words, the bunker can contain as many as 72 tote boxes. A single tote box can be loaded up to $40-80 \mathrm{~kg}$ of products depending on its densities. 


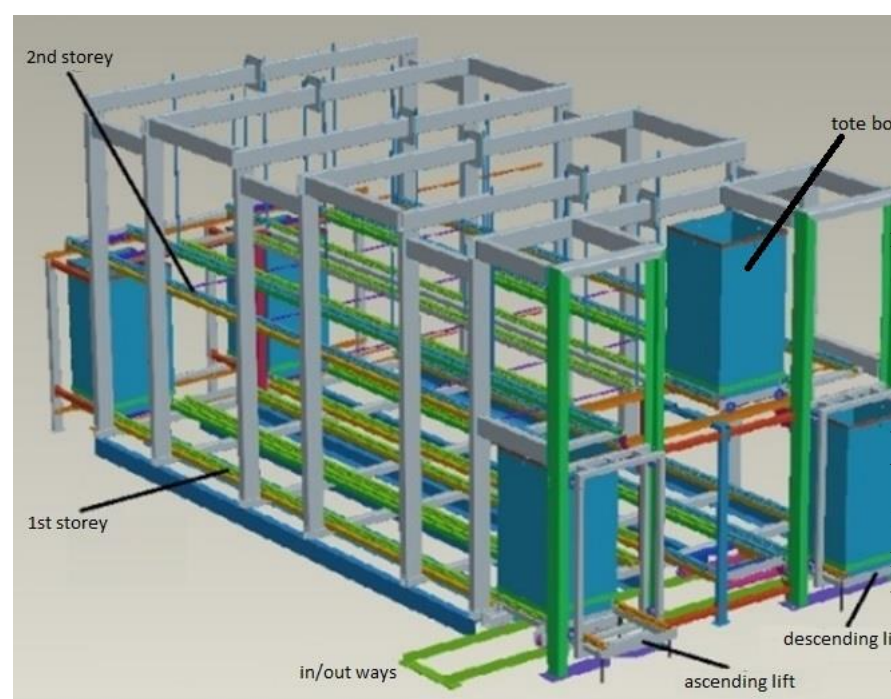

Fig. 2. Source pass mechanism

The most important mechanical parameter is cycle time. The cycle time is time needed for completing one cycle of the source pass mechanism. Cycle times were already observed and the minimum operational cycle time was decided to 70 seconds. Since there are 72 irradiation positions, the product will be irradiated for minimum of 84.0 minutes. This parameter is important for the acceptance of a minimum absorbed dose.

The above cycle time is the characteristic of the existing IGMP. If needed, the cycle time can be reduced. A simple manner is just by modifying the speed setting of the pneumatic cylinders. Or, it is done by modifying the design of the product transport system, especially on the movement step procedure of tote boxes [13]. The design of the pneumatic cylinders for the product transport system were well discussed in Ref [14].

\subsection{Installation of Cobalt-60 sources}

The IGMP was loaded with $301 \mathrm{kCi}$ of Cobalt-60 sources distributed into 29 rods, which each source contains 10 to $11 \mathrm{kCi}$ [1]. IGMP was designed as multipurpose gamma irradiator facility, therefore IGMP should allow for the use of low to high irradiation doses. The configuration of the rod sources in the source racks use 4-21-4 configuration: 4 rods for left rack (Rack 3), 4 rods for the right rack (Rack 1) and 21 rods for the middle rack (Rack 2).

The source rack hoist mechanism is controlled by PLC programme. There are many combinations in lifting the source racks, yet only 4 options are provided by the control system:

- Option 1: $41.25 \mathrm{kCi}$ (only Rack 1 is lifted, low dose) - Option 2: $82.48 \mathrm{kCi}$ (Rack 1 and 3 are lifted, low dose) - Option 3: $219.04 \mathrm{kCi}$ (only Rack 2 is lifted, high dose) - Option 4: $301.51 \mathrm{kCi}$ (all racks are lifted, high dose).

\subsection{Dosimetry characterization}

Dosimetry characterization was performed using dummy and by operating the IGMP for 12 hours in July 2017. All racks were activated, so that its total activities were about $301 \mathrm{kCi}$. The density of irradiated product was $0.067 \mathrm{gr} / \mathrm{cm}^{3}$. Experimental data showed that the average of absorbed doses was about $21.1 \mathrm{kGy}$ with the rate of $1.76 \mathrm{kGy} / \mathrm{h}$. The ratio between maximum and minimum doses (DUR) is important. The experimental data gave a ratio of 1.29 . Attention must be paid since the average dose, dose rate and DUR are dependent with the product density.

By interpolation method, low dose rate application an be obtained by lifting only Rack 1 (Option 1), thus the activity will be $41.2 \mathrm{kCi}$. The average absorption rate becomes $0.24 \mathrm{kGy} /$ hour. As the minimum duration of the irradiation process is 84.0 minutes, the absorbed dose of minimum irradiation can be predicted at $0.34 \mathrm{kGy}$. From the experiment, it is obvious that IGMP can operate from

low to high dose. Since Cobalt-60 sources decay every time (the activities become half its original value after 5.27 years), the dose rate and the minimum dose will decrease.

\section{DISCUSSION}

\subsection{Gamma irradiators in Neighbouring Countries}

Table 1 shows that most of the neighbouring countries have been using irradiator technology since long time. In 2002, Indonesia despite having wide and large territory, has only one commercial irradiator (owned by PT. RelIon) while other countries have more than one facility. As we can see in the Table 1, in 2013 most countries build more gamma irradiator facilities compared to 2002 . China as example, had significant number of irradiator facilities as much as 103 in total. Our neighbours: Malaysia, Thailand, and Vietnam had built 2, 4 and 2 gamma irradiators respectively.

Table 1. Commercial Gamma Irradiator facilities in neighbouring countries

\begin{tabular}{|c|l|c|c|}
\hline \multirow{2}{*}{ No } & \multirow{2}{*}{ Country } & \multicolumn{2}{|c|}{ Number of irradiators } \\
\cline { 3 - 4 } & & $\mathbf{2 0 0 2} *$ & $\mathbf{2 0 1 3} * *$ \\
\hline 1 & Australia & 2 & 3 \\
\hline 2 & Bangladesh & 2 & 2 \\
\hline 3 & China & 21 & 103 \\
\hline 4 & India & 1 & 9 \\
\hline 5 & Indonesia & 2 & 1 \\
\hline 6 & Japan & 1 & 2 \\
\hline 7 & Korea (Republic of) & 4 & 6 \\
\hline 8 & Malaysia & 1 & 1 \\
\hline 9 & Philippines & 2 & $* * *$ \\
\hline 10 & Taiwan & 4 & 8 \\
\hline 11 & Thailand & 1 & 3 \\
\hline 12 & Vietnam & - & 4 \\
\hline 13 & Pakistan & 3 & $*$ \\
\hline
\end{tabular}

* Source: IAEA-DGPF/CD, ISBN 92-0-100204-1 document, February 2004

** Gathered from various sources

*** No information 
Gamma irradiator facility managed by PT. Rel-Ion was the only industrial gamma irradiator in Indonesia that had been operating since 1991. Although it is already more than 25 years, other private sectors had not followed the development of gamma irradiators. Even now, private sectors tend to be reluctant to invest in gamma irradiator facility. Nowadays, PT. Rel-Ion's capacity to perform irradiation tends to be overload, so that consumers have to queue to get an irradiation service. Deal with those realities, BATAN planned to promote the use of gamma irradiator nationwide.

\subsection{Gamma Irradiators for plant industries}

Indonesia has abundant agricultural products for domestic consumption or being exported overseas. Since Indonesia has a very wide territory from Sabang to Merauke, the food can undergo damage by the microorganism or sprout growth when distributed. It is also happened with the exports. Consequently, the food commodities cannot be evenly distributed nationwide or worldwide. Irradiation technique can be a solution for the delivery problems, since it can kill microorganisms, prevent the growth of sprout and delay the ripening. It also can reduce the usage of chemical preservatives which are dangerous for human body if being consumed for a long time and large amount.

Based Gamma irradiators can be used to assist the quarantine process of fresh fruits or vegetables that will be exported abroad. Irradiation techniques for phytosanitary have been allowed according to SNI 8726 : 2019 standards [15]. This standard provides procedures for the process of radiation of fresh agricultural products, such as fruits, vegetables, and cut flowers for phytosanitary treatment. This standard is directed primarily to the treatment needed to control regulated pests related to fresh agricultural products. The absorbency dose range used for phytosanitary treatment is between 150 gray (Gy) and 600 gray (Gy). Most fresh agricultural products are not negatively affected at the minimum allowable dose. Specifically, the fruits that have proved to be tolerant of the minimum dose are as follows: apples, cantaloupe, star fruit, cherries, oranges, raisins, dates, figs, grapes, guava, melons, kiwi, lychees, mangoes, muskmelon, nectarine, papaya, peaches, plums, raspberries, strawberries, and tomatoes.

Based on study that have been conducted by many researchers, absorbed doses of irradiation needed both for preservation and for extending the shelf life of agricultural products vary from low doses to high doses. All doses from 1.0 to $7.0 \mathrm{kGy}$ can be obtained efficiently by using gamma irradiation facility with either low or high doses options. From that, it can be concluded that the IGMP can answer almost all of the desired dosage requirements.

One of the promising agricultural products for export is cocoa (Theobroma cacao L.). Nowadays, Indonesia is the third largest cocoa producing and exporting country. The five biggest provinces of cocoa producers according to 2016 data are West Sumatera (53,400 ton); West Sulawesi (57,600 ton); Central
Sulawesi (118,300 ton); Southeast Sulawesi (100,600 ton) and South Sulawesi (102,700 ton). In total, Indonesia produced more than 600,000 tonnes of cocoa [16]. To be exported overseas, the cocoa bean should meet the criteria from SNI 2323:2008 which is already amended two times in 2010. According to the standard [17], inside the cocoa bean, there are must be no living insects, no smell of smokes, no foreign matter content, and water content $\max 7.5 \%$. These requirements can be complied with irradiation technology. In Indonesia itself, cocoa can be processed into cocoa powder, and reportedly has been irradiated as much as 2,311 ton in 2005 [18]. In 2010 as much as 6923 tons of food was irradiated, including cocoa $(80 \%)$, spices $(5 \%)$, and others [19].

From the previous studies, there were moulds found in cocoa beans during and post harvesting process. They were from genus Aspergillus, Penicillium, Fusarium, Rhizopus, and Mucor [20,21,22]. Moulds that grow on fruits could be reduced by irradiation treatment with irradiation dose of 1.5 to $3.5 \mathrm{kGy}$ [23]. Referring to the regulation of the Minister of Health [3], processed vegetable and fruit products can be treated with irradiation to extend the shelf life with irradiation dose up to $7 \mathrm{kGy}$. Aside from the discovery of moulds on the cocoa beans, the presence of bacteria also were found, such as coliform and Salmonella [24]. Granados [25] studied that cocoa beans already undergo irradiation for eliminating the bacterial load using Gamma Irradiation with Co-60 source and irradiation doses of 2, 3 and 5 $\mathrm{kGy}$. The dose of 3 and $5 \mathrm{kGy}$ were reportedly effective to control the growth of enterobacteria and Salmonella.

Nowadays, IGMP irradiates various products every day. Many of private companies use IGMP for processing of their products. One of the IGMP's customer is cocoa company. In the end of 2018, every week about $5,760 \mathrm{~kg}$ cocoa powder are irradiated in IGMP. This amount is performed by operating IGMP twice for about 4 hours. Suppose that IGMP are consigned only for cocoa, it would be able to process about 4,800 tonnes per year. According to the data on cocoa production in Indonesia which is about 600,000 tonnes per year. Cocoa is not a seasonal crop. In other words, cocoa products are produced throughout the year. This condition is in accordance with the characteristic of the gamma irradiator which will be economical if it is operated continuously. So that we can consider that the needs of gamma irradiator facilities in Indonesia for cocoa products are mathematically more than a hundred.

Cocoa is not the only one of the island of Sulawesi's agricultural products. There are many more agricultural products that are scattered throughout the territory of Indonesia, it is necessary to build gamma irradiation facilities in areas that have large agricultural yields. This way can minimalize the crop losses and increase the quality of the agricultural products.

IGMP is a multi-purpose gamma irradiator facility and now operating daily. Various products from numerous private companies are irradiated in the IGMP such as: herbal tea, cocoa powder, food, seaweed, etc. By the time, the number of IGMP's customers, as well as 
their quantity to be processed, are increasing. Apparently, irradiation technique becomes appropriate technology for Indonesia.

\section{CONCLUSION}

IGMP which was designed up to $2 \mathrm{MCi}$ using Cobalt-60 as radioactive sources can be used as food preservation and other purposes. It can cover the desired dosage requirements for each purpose of treatment. The facility is also economic for continuous usage. It is then ideal for Indonesian agricultural products. Case study on cocoa showed that more and more gamma irradiators are needed for only this product. By using irradiation treatment with gamma irradiators, cocoa and almost all agroindustrial products can be distributed nationwide and worldwide and also can increase their market value. Gamma irradiation facility can play very important role for plant industries, since Indonesia has abundant agricultural products which is spread throughout the territory.

\section{REFERENCES}

1. A. Satmoko, H. A. Gunawan, B. Rozali, W. Budiyono, Prosiding Seminar Pendayagunaan Teknologi Nuklir, ISSN: 2540-8062, pp. 196 (2017)

2. Presiden Republik Indonesia, Undang-Undang Republik Indonesia No. 18 Tahun 2012 tentang Pangan, pp. 1-83 (2012)

3. Menteri Kesehatan Republik Indonesia, Peraturan Menteri Kesehatan Republik Indonesia No 701/MENKES/PER/VIII/2009 tentang Pangan Iradiasi (2009)

4. BPOM, Cara Iradiasi yang Baik untuk Membasmi Serangga pada Biji-bijian Serelia, ISBN 97998509-4-0, pp. 4-5 (2004)

5. Institute of Isotopes, Main Features of the Facility Servo Type Multipurpose, Institute of Isotopes Co., Ltd. (2015)

6. Kristiyanti, E. Karyanta, PRIMA Bulletin, ISSN 1411-0296, 11 (2014)

7. T. Ardiyati, B. Rozali, R. Damayanti, Prosiding Seminar Nasional Pendayagunaan Teknologi Nuklir, ISSN 1878-3515 (2016)

8. T. Ardiyati, B. Rozali, Kasmudin, J. Phys : Conf. Ser, no. 11, pp. 1-7 (2018)

9. T. Ardiyati, Kasmudin, Prosiding Seminar Nasional Aplikasi Isotop dan Radiasi, ISBN : 978-979-355829-5, pp 163-169 (2018)

10. H. Saptowati, K. Prayogo, Jurnal Perangkat Nuklir, ISSN 1978-3515, 09, pp. 80-89 (2015)

11. A. Satmoko, H. A. Gunawan, Jurnal Perangkat Nuklir, ISSN 1978-3515, 09, pp. 70-79, (2015)

12. Institute of Isotopes, Preliminary Operation And Maintenance Manual For TBI-8250-140 Type Tote Box Gamma Irradiator 2017 Installed at Jakarta,
Ref.N. ST1546-2016K, Institute of Isotopes Co., Ltd., 2 (2017)

13. A. Suntoro, Jurnal Perangkat Nuklir, ISSN 19783515, 09, pp. 60-69, (2015)

14. M. Subhan, A. Satmoko, Jurnal Perangkat Nuklir, ISSN 1978-3515, 10, pp. 50-61, (2016)

15. Badan Standardisasi Nasional, SNI 8726:2019. Indonesia (2019)

16. Badan Pusat Statistik, Statistik Kakao Indonesia. Jakarta: Badan Pusat Statistik (2016)

17. Badan Standardisasi Nasional, SNI 2323:2008. Indonesia (2008)

18. T. Kume, M. Furuta, S. Todoriki, N. Uenoyama, and Y. Kobayashi, Radiat. Phys. Chem., 78, no. 3, pp. 222-226 (2009)

19. I.C.F.R. Ferreira, A.L Antonio, S.C. Verde, Food Irradiation Technologies : Concepts, Application, and Outcomes (2018)

20. Asrul, Agroland, 16, pp. 258-267 (2009)

21. O. Dharmaputra, Sunjaya, I. Retnowati, and S. Ambarwati. Biotropia (Bogor), no. 15, pp. 58-75 (2000)

22. W. Amaria, T Iflah, R. Harni. Bunga Rampai : Inovasi Teknologi Bioindustri Kakao, pp. 199-212 (2014)

23. N. Aziz, L. Mousa. Food Control, 13, pp. 281-286 (2002)

24. M. Ariyanti, Suprapti. Jurnal Standardisasi, 18, no. 1, pp. 52-60 (2016)

25. A. F. Granados, N. R. Quiñones, F. F. Garboggini, P. Efraim, and M. C. T. Duarte. Procedia Food Sci., 7, pp. 5-8 (2016) 